\title{
QUALITY CONTROL OF SEASONAL INFLUENZA VACCINES
}

\author{
Tamara MANDUŠIĆ NAZOR, Marta PIPIĆ KOSANOVIĆ, and Siniša TOMIĆ \\ Agency for Medicinal Products and Medical Devices, Zagreb, Croatia
}

Received in February 2010

Accepted in October 2010

\begin{abstract}
The purpose of seasonal influenza vaccination is to prevent its spread. The vaccines contain strains of the influenza virus recommended and approved for a particular season. Just like any other medicinal product, all vaccines require marketing approval. Batches of approved vaccines are extensively tested by the manufacturers and additionally controlled by the approving authorities, which issue the quality control certificates. This article not only to describes the legal background of quality control, but also how control test results obtained by a Croatian official control laboratory are compared to manufacturer's results. We have found that testing results can slightly differ depending on methods/analytical procedures used in different laboratories. This investigation has also shown how important it is to test finished medicinal products, independently of testing at intermediate stages, and how retesting by control authorities ensures that marketed vaccines meet quality standards.
\end{abstract}

KEY WORDS: epidemiology, influenza virus, Official Control Authority Batch Release (OCABR), Official Medicines Control Laboratory (OMCL)

Influenza (flu) is an acute infectious disease caused by influenza viruses, which spreads quickly and has high morbidity. Influenza viruses belong to the family Orthomyxoviridae and are classified according to their antigen differences (internal antigens) into types A, B, and C. Influenza viruses have two antigens (glycoproteins) on their surface: haemagglutinin (HA) and neuraminidase (NA). These surface antigens change rapidly and unpredictably, rendering the immune system vulnerable all over again every year. Changes are either large and are called shifts, which are rare, and minor, called drifts, which occur practically every year (1). Repeated (seasonal) vaccination is the effective way to prevent the spread of the disease. Every year, World Health Organisation (WHO) issues an overview of the epidemiological state of the influenza virus worldwide, and recommends which predominant strains of types $\mathrm{A}$ and $\mathrm{B}$ should be used in vaccines for the coming season. Type $\mathrm{C}$ influenza is not included because it is far less frequent than A and B types and usually causes very mild respiratory symptoms or no symptoms at all. It does not cause epidemics and does not much burden public health.

Following the WHO recommendations, European Union (EU) experts decide which strains to use for the coming season, bearing in mind the epidemiological situation in the EU (2). For the season 2009/2010, the WHO recommended the following strain composition for the northern hemisphere: A/Brisbane/59/2007 (H1N1)-like virus, A/Brisbane/10/2007 (H3N2)like virus, and $\mathrm{B} / \mathrm{Brisbane} / 60 / 2008$-like virus (3). Following this recommendation, vaccine manufacturers used reassorted strains that give high yields of required surface antigens (4).

Seasonal influenza vaccines are sterile suspensions of strains of two types of influenza viruses - type A (subtypes H1N1 and H3N2) and type B. The vaccines are produced in such a way that the vaccine primarily contains the HA and NA antigens, without diminishing 
the antigenic characteristics of those antigens. The potency of the vaccine, i.e. the stated amount of the haemagglutinin antigen present in the vaccine per strain per dose is 15 micrograms $(\mu \mathrm{g})$ unless clinical evidence supports the use of a different amount (4). Neither the European Pharmacopoeia (4) nor the guidelines issued by the Committee for Proprietary Medicinal Products (CPMP) require defining the content of the neuraminidase antigen (2).

In Croatia, 2009/2010 seasonal vaccination included two types of vaccines: surface antigen, inactivated, and split virion, inactivated, both approved by the Agency for Medicinal Products and Medical Devices (HALMED). Pursuant to the Medicinal Products Act (5), the same institution performs quality control of medicinal products prior to marketing. The purpose of quality control is to establish compliance with quality standards defined in marketing approval. A special form of quality control for immunological medicinal products and medicinal products derived from blood or plasma is conducted by both the manufacturer and independent authority, in Croatia's case by HALMED. Immunological medicinal product is a medicinal product that is or contains vaccine, toxin, serum or allergen $(5,6)$.

In the European Union (EU), quality control is conducted by the Official Medicines Control Laboratory (OMCL), which is independent from the manufacturer, to ensure safety and quality of medicinal products in use $(7,8)$. HALMED participates in the OMCL network, but until Croatia becomes an EU Member State, it cannot participate in the Official Control Authority Batch Release (OCABR) procedure $^{1}$. The procedure ensures that the quality of immunological medicinal products is tested in only one laboratory in the EU, and the issued certificate is used by OMCLs in the Member States when implementing OCABR at a national level, following the requirements of Directive 2001/83/EC, as amended by Directive 2004/27/EC ${ }^{2}$. The OMCL conducting the testing of the influenza vaccine is obliged to test the following pursuant to the guidelines: appearance,

\footnotetext{
${ }^{1}$ The EDQM acts as the Secretariat for OCABR network activities, as mandated by the European Commission

2 The Member State contacts the marketing authorisation holder (MAH) to indicate a need for OCABR certificates for batches of a product on their market. Samples of the batch to be released are sent, along with production and control protocols, to an OMCL within the EC. If the results are satisfactory, the CA issues an 'Official Control Authority Batch Release Certificate' to the MAH This OCABR certificate means that the batch has been examined and tested by an OMCL, in accordance with the OCABR guidelines pertaining to the medicinal product, and is in compliance with the approved specification laid down in the relevant monographs of the European Pharmacopoeia and in the relevant marketing authorisation (9).
}

haemagglutinin antigen concentration/identity, bacterial endotoxin content, while purity is tested on the first five lots of a monovalent bulk following the introduction of a new influenza strain $(9,10)$.

In Croatia, each batch of an immunological medicinal product is subject to special (double) quality control, regardless of whether it has the OCABR certificate. The applicant must submit to HALMED sufficient quantities of samples for analysis, manufacturer's certificate of analysis for the batch in question, manufacturer's production documentation, and quality control and the batch release certificate issued by the relevant agency in manufacturer's country or the EU. If requested, the applicant should also submit a sufficient number of samples of the original raw materials and their test reports (6). Before applying for independent quality control, the vaccine manufacturer has to perform tests on the intermediates and on the finished product. One of the tests on the finished product is potency testing, i.e. determining haemagglutinin antigen in the the vaccine filled in the primary containers. An other test the manufacturer performs only on the first three monovalent pooled harvests from each working seed lot is the test for the presence and the type of neuraminidase $(4,10)$.

In addition to other tests mentioned earlier, the control laboratory does the potency testing in the finished product, pursuant to the OCABR guidelines for influenza vaccines(10). HALMED follows the same quality control procedure. However, time requirements are tight. Whenever WHO recommends a new strain to be included in the vaccine, manufacturing process for the new strain has to be revalidated and report submitted to regulatory authorities. In addition, the manufacturer has to obtain an international reagent specific to the selected strain to measure the concentration of each HA antigen (11).

The objective of this article is to present special (double) quality control procedure and compare control test results to manufacturer's to see if there are and what are the causes of discrepancies.

\section{MATERIALS AND METHODS}

\section{Samples}

Samples of seasonal flu vaccine (2009/2010) were tested in four laboratories. HALMED laboratory (Lab 1) and EU OMCL laboratory (Lab 2) tested two 
Table 1 Testing reagents

\begin{tabular}{lc}
\hline Reagents & Producer \\
\hline Agarose (for 1\% agarose gel) & Sigma Aldrich, Switzerland \\
\hline $\begin{array}{l}\text { Specific/reference polyclonal antibodies: } \\
\text { Influenza Anti-A/Brisbane/59/2007 (IVR-148) (H1N1) HA serum, 08/112; }\end{array}$ & $\begin{array}{c}\text { National Institute for Biological } \\
\text { Standardisation and Control } \\
\text { Influenza Anti-A/Brisbane/10/2007 (H3N2)-Like HA, NIBSC, 08/246; }\end{array}$ \\
$\begin{array}{lc}\text { Influenza anti-B/Brisbane/60/08 HA serum, 08/354 } \\
\text { Reference antigens: }\end{array}$ & $\begin{array}{c}\text { National Institute for Biological } \\
\text { Influenza Antigen A/Brisbane/59/2007 (IVR-148) (H1N1), 08/100; }\end{array}$ \\
$\begin{array}{l}\text { Influenza Antigen A/Uruguay/716/2007 (H3N2) (NYMC-175C), 08/278; } \\
\text { Influenza B/Brisbane/60/08 antigen Reagent, 08/352. }\end{array}$ & (NIBSC), United Kingdom \\
\hline Reaction stop solution: & HALMED, Croatia \\
Dulbecco Phosphate buffered saline (PBS) & Sigma Aldrich, USA \\
\hline $\begin{array}{l}\text { Staining solution: } \\
\text { Comassie brilliant blue + destaining solution }\end{array}$ & Kemika, Croatia \\
\hline $\begin{array}{l}\text { Destaining solution: } \\
\text { Acetic acid + methanol + distilled water }\end{array}$ & Fluka, Germany \\
\hline Zwittergent 3-14 detergent & \\
\hline
\end{tabular}

batches of the finished product (batches A and B) produced from the same final bulk $(\mathrm{FB})^{3}$ and samples of that final bulk. The manufacturer of the finished product (Lab 3) tested the same samples as Lab 1 and 2, while the manufacturer of the final bulk (Lab 4) tested only the batch of the final bulk All test results were delivered to HALMED.

\section{Reagents and methods}

Table 1 shows all materials used for testing.

The content of haemagglutinin antigens in influenza vaccines was tested using the single radial immunodiffusion (SRID) method, as described in the European Pharmacopeia (4) ${ }^{4}$. This method is not affected by purification of surface antigens or virus dissociation used in vaccine production. Specificity is achieved with specific antiserums, and can serve to compare two antigen preparations (14). The method is based on passive diffusion of antigens into an agarose gel containing uniformly distributed antibodies. Upon the first contact of the antigen with an antibody soluble complexes are formed, while with further penetration of the antigen through the agar, the concentration of the antigen drops. When the optimum concentration ratio of antigens and antibodies is obtained, an insoluble precipitation ring is formed, which is round

\footnotetext{
${ }^{3}$ The final bulk (FB) is produced by blending the necessary/appropriate quantities of monovalent pooled harvests (active compounds for each individual virus strain). Final bulk (FB) filled into the primary containers after labelling and packaging becomes Final product (4).

${ }^{4}$ The SRID method is based on the method by Wood et al. (12) with several modifications. The method was first used as a method for testing influenza vaccine value in $1978(13)$
}

in shape (15). This ring confirms the identity of vaccine antigen and it is measured to calculate (and therefore quantify) the content of HA in the vaccine. Each laboratory has its own standard operating procedure for the SRID method. Lab 1 followed the procedure of the manufacturer of the finished product. The agarose solution was prepared by adding an optimal quantity of specific antiserum in the volume necessary to precipitate individual virus strains ${ }^{5}$. The agarose/antiserum mixture was poured onto glass plates and allowed to cool. The plates were placed in a humid, dark chamber and left at $+4^{\circ} \mathrm{C}$ until the following day. Wells $4 \mathrm{~mm}$ in diameter were punched into the resulting gel for inoculation with $20 \mu \mathrm{L}$ of the diluted reference antigen, i.e. vaccine sample.

Reference antigens were dissolved according to the NIBSC instructions and/or vaccine manufacturer's qualification report. A series of vaccine sample solutions and reference substances were prepared using Zwittergent 3-14 detergent and PBS in the appropriate dilutions for vaccine samples and reference antigens $(1: 1,3: 4,1: 2$, and 1:4). The tested solutions were inoculated in triplicate and the reference substances in duplicate. The prepared plates were stored in a humid, dark chamber at room temperature for 24 hours to allow for diffusion of the antigen and reaction between the antigens and antibodies. The reaction was stopped by sinking the plate into a prepared

\footnotetext{
${ }^{5}$ The quantity of each antiserum is stated on the antiserum certificate. The quantity of the necessary specific antiserum for obtaining sharp precipitation rings is established by the vaccine manufacturer in a series of preliminary tests for the flu vaccine for the $2009 / 2010$ season.
} 
solution, and the plates were left to dry. After drying, the plates were stained to make precipitation rings visible and destaining of the background made the rings appropriate for reading.

The precipitation rings were measured using a glass magnifier which magnifies 7 times and antigen content was obtained following the procedure described by Williams (13). The content of haemagglutinin antigen is calculated using the software program CombiStats v4.0, EDQM (16).

\section{RESULTS AND DISCUSSION}

The specifications for haemagglutinin antigen content for all three strains of the influenza virus were taken from the European Pharmacopoeia. The declared content per strain for the finished product (final lot) is $15 \mu \mathrm{g} /$ dose and the lower limit is $\geq 12 \mu \mathrm{g} /$ dose (4).

Table 2 shows Lab 1 and Lab 3 test results for two batches $\mathrm{A}$ and $\mathrm{B}$ of the finished product and $\mathrm{Lab}$ 4 results for the final bulk. The number of replicates tested by Lab 1 was one per batch for Type A (H1N1) A/Brisbane/59/2007, IVR - 148 and Type B $\mathrm{B} / \mathrm{Brisbane} / 60 / 2008$, but three replicates per batch for Type A (H3N2) A/Uruguay/716/2007, NYMCX-175C because the first result did not match specification. Retesting followed HALMED's standard operating procedure.

Table 2 shows good agreement between the results of Labs 1, 3, and 4 for Type A, (H1N1) A/Brisbane/59/2007, IVR-148, and Type B, B/ Brisbane/60/2008, and deviation in Lab 4 result in the final bulk for Type A (H3N2), strain A/ Uruguay/716/2007 NYMCX-175C.

The repeated control testing of the finished product in Lab 1 confirmed the low content of haemagglutinin for Type A (H3N2), strain A/Uruguay/716/2007 NYMCX-175C, which is why Lab 1 performed additional quality control of the final bulk.

Table 2 Haemagglutinin antigen content for three viral strains in 2009/2010 season influenza vaccine for the finished product (Labs 1 and 3) and final bulk (Lab 4)

\begin{tabular}{|c|c|c|c|c|c|}
\hline \multirow{4}{*}{ Virus strain } & \multicolumn{5}{|c|}{$\begin{array}{l}\text { Content of haemagglutinin antigen (lower estimated value) } \\
\qquad / \mu \mathrm{g} \text { per dose }\end{array}$} \\
\hline & \multicolumn{4}{|c|}{ Finished product } & \multirow{3}{*}{$\begin{array}{c}\text { Final bulk } \\
\text { Lab } 4\end{array}$} \\
\hline & \multicolumn{2}{|c|}{ Lab 1} & \multicolumn{2}{|c|}{ Lab 3} & \\
\hline & Batch A & Batch B & Batch A & Batch B & \\
\hline $\begin{array}{l}\text { Type A (H1N1) A/Brisbane/59/2007, } \\
\text { IVR-148, (A/Brisbane/59/2007-like) }\end{array}$ & 16.00 & 13.94 & 15.09 & 15.21 & 16.64 \\
\hline Type A (H3N2) A Uruguay/716 & 11.00 & 10.89 & & & \\
\hline /2007, NYMCX-175C, (A/ & 10.63 & 12.28 & 11.06 & 11.35 & 15.76 \\
\hline Brisbane/10/2007-like) & 11.12 & 10.35 & & & \\
\hline Mean Value (MV) Type A (H3N2) & 10.92 & 11.17 & 11.06 & 11.35 & 15.76 \\
\hline $\begin{array}{l}\text { Type B B/Brisbane/60/2008, (B/ } \\
\text { Brisbane/60/2008-like) }\end{array}$ & 15.18 & 15.86 & 15.16 & 14.91 & 16.20 \\
\hline
\end{tabular}

Table 3 Haemagglutinin antigen content for Type A (H3N2), strain A/Uruguay/716/2007 NYMCX-175C in the final bulk (Labs 1-3) and finished product (for Lab 2).

\begin{tabular}{|c|c|c|c|c|c|}
\hline \multirow{4}{*}{ Virus strain } & \multicolumn{5}{|c|}{$\begin{array}{l}\text { Content of haemagglutinin antigen (lower estimated value) / } \\
\qquad / \mu \text { ger dose }\end{array}$} \\
\hline & \multicolumn{3}{|c|}{ Final bulk } & \multirow{2}{*}{\multicolumn{2}{|c|}{$\begin{array}{c}\text { Finished product } \\
\text { Lab } 2 \\
\end{array}$}} \\
\hline & \multirow{2}{*}{ Lab 1} & \multirow{2}{*}{ Lab 3} & \multirow{2}{*}{ Lab 2} & & \\
\hline & & & & Batch A & Batch B \\
\hline $\begin{array}{l}\text { Type A (H3N2) A/Uruguay/716/2007, } \\
\text { NYMCX-175C, }\end{array}$ & 11.24 & & & & \\
\hline \multirow[t]{3}{*}{ (A/Brisbane/10/2007-like) } & 9.81 & 10.16 & 11.82 & & \\
\hline & 10.97 & 10.45 & 12.16 & 11.96 & 11.95 \\
\hline & 10.00 & & & & \\
\hline Mean Value & 10.51 & 10.31 & 11.99 & 11.96 & 11.95 \\
\hline
\end{tabular}




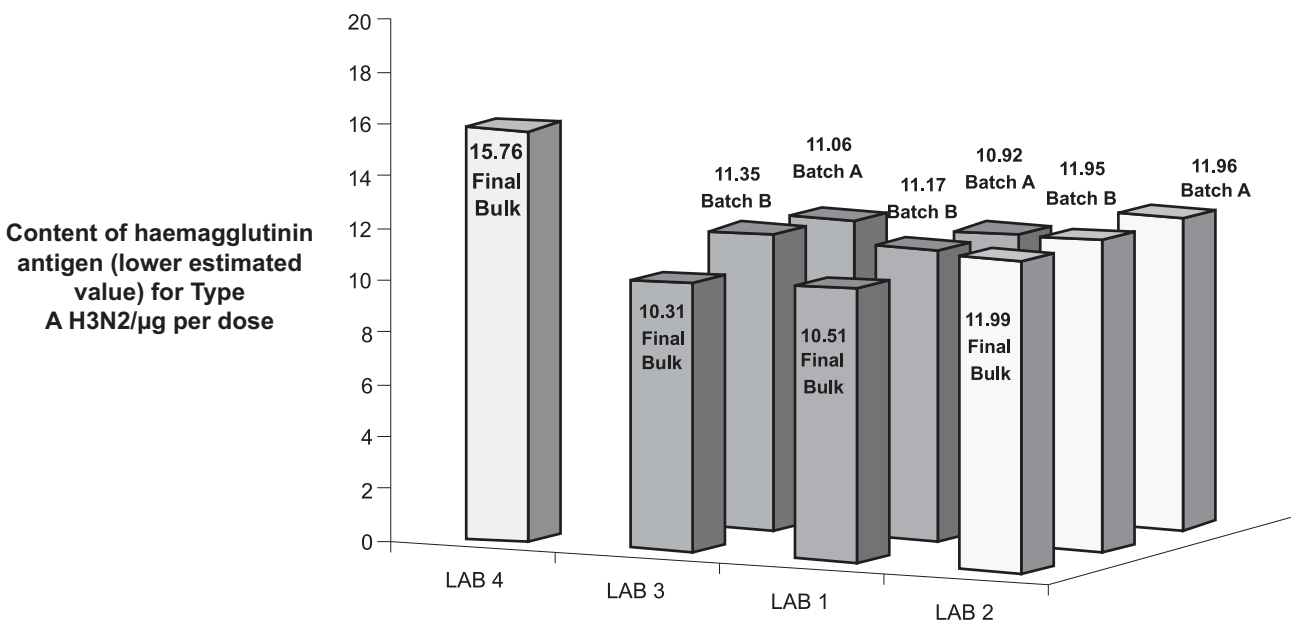

Figure 1 Comparison of haemagglutinin antigen content (lower estimated value) for Type A (H3N2) influenza virus, strain A/Uruguay/10/2007 NYMCX-175C between Labs 1-4. The results are given as means.

Lab 2 tested the same batches of the finished product and of the final bulk as did Labs 1 and 3. Table 3 compares haemagglutinin antigen content for the Type A (H3N2) virus, strain A/Uruguay/716/2007 NYMCX-175C. The results are represented as individual values and their means. There is a good agreement, with minor deviations, between Labs 1, 2 , and 3. Lab 1 and 3 got the results that did not meet specification and Lab 2 results were bordering on the lower limit for both the final bulk and the finished product (Figure 1).

Considering that the tests were conducted on immunological medicinal products, whose active substances are of biological origin, the results may show variations under different testing conditions, even if the same methods/analytical procedures are applied. The test results confirm the importance of testing the finished product (final lot) and not just the final bulk, and the importance of testing batch samples by a control laboratory before marketing.

\section{ACKNOWLEDGEMENTS}

The authors would like to acknowledge Ms Laila Stefanini Orešić for critical review of the manuscript.

\section{REFERENCES}

1. Puntarić D. Bolesti koje se prenose preko dišnog sustava [Infectious respiratory disease, in Croatian]. In: Ropac D, editor. Epidemiologija zaraznih bolesti [Epidemiology of infectious disease, in Croatian]. $1^{\text {st }}$ ed. Zagreb: Medicinska naklada; 2003. p. 142-4.

2. The European Agency for the Evaluation of Medicinal Products (EMEA). Committee for proprietary medicinal products (CPMP). Note for guidance on harmonisation of requirements for influenza vaccines [displayed December 2009]. Available at http://www.ema.europa.eu/pdfs/human/ bwp/021496en.pdf.

3 World Health Organization (WHO). Global Alert and Response (GAR). Recommended composition of influenza virus vaccines the $2009-2010$ northern hemisphere influenza season [displayed 22 September 2009]. Available at http:// www.who.int/csr/disease/influenza/recommendations2009 10north/en/index.html.

4. Council of Europe. European Pharmacopoeia 6.0. Strasbourg Cedex: Directorate for the Quality of Medicines \& HealthCare of the Council of Europe (EDQM); 2007.

5. Zakon o lijekovima [Medicinal Products Act, in Croatian]. Narodne novine 71/2007.

6. Pravilnik o načinu provjere kakvoće lijeka [Ordinance on Quality Control of Medicinal Products, in Croatian]. Narodne novine 56/2005

7. European Directorate for the Quality of Medicines \& HealthCare (EDQM). OMCL Network of the Council of Europe GENERAL DOCUMENT, PA/PH/OMCL (07) 89 8R, GEON Terms of reference Annex 1: Definition of an OMCL and OMCL Status within the GEON [displayed December 2009]. Available at https://www.edqm.eu/medias/ fichiers/Annex 1 to the GEON_Terms of Reference Definition_pdf.

8. Milne C, Buchheit KH, Spieser JM. The EU/EEA network for official control authority batch release of biologicals for human use. RAJ Pharma 2002;13:477-83.

9. European Directorate for the Quality of Medicines (EDQM). Official Control Authority Batch Release (OCABR) for Human Biologicals: Vaccines, blood and plasma derivatives [displayed December 2009]. Available at https://www.edqm. eu/en/Human_Biologicals_OCABR-611.html. 
10. European Directorate for the Quality of Medicines (EDQM). OMCL Batch Release Guidelines [displayed December 2009]. Available at https://www.edqm.eu/en/Batch-ReleaseGuidelines-85.html

11. Gerdil C. The annual production cycle for influenza vaccine. Vaccine 2003;21:1776-9.

12. Wood JM, Schild GC, Newman RW, Seagroatt V. An improved single-radial-immunodiffusion technique for the assay of influenza haemagglutinin antigen: application for potency determinations of inactivated whole virus and subunit vaccines. J Biol Stand 1977;5:237-47.

13. Williams MS. Single-radial-immunodiffusion as in vitro potency assay for human inactivated viral vaccines. Vet Microbiol 1993;37:253-62.
14. Rodda SJ, Gallichio HA, Hampson AW. The single radial immunodiffusion assay highlights small antigenic differences among influenza virus hemagglutinins. J Clin Microbiol 1981;14:479-82.

15. Čvorišćec D, Plavšić V. Imunokemijske metode [Immunochemical methods, in Croatian]. In: Štraus B, Stavljenić RA, Plavšić F, editors. Analitičke tehnike u kliničkom laboratoriju [Analytical techniques in clinical laboratory, in Croatian]. $1^{\text {st }}$ ed. Zagreb: Medicinska naklada; 1997. p. 157-8.

16. European Directorate for the Quality of Medicines \& HealthCare (EDQM) [displayed December 2010]. Available at http://combistats.edqm.eu/images/stories/Examples/ Influenza.pdf 


\section{Sažetak}

\section{PROVJERA KAKVOĆE CJEPIVA ZA SEZONSKU GRIPU}

Za prevenciju i suzbijanje širenja gripe kao zarazne bolesti svake se godine provodi sezonsko cijepljenje cjepivima koja u svom sastavu sadržavaju sojeve virusa influence preporučene i odobrene za tu sezonu. Da bi se mogla staviti u promet, sva cjepiva moraju od nadležnog tijela dobiti dozvolu za stavljanje u promet kao i drugi lijekovi. Puštanje u promet proizvedenih serija odobrenog cjepiva zahtijeva osim opsežnih ispitivanja od strane proizvođača i dodatnu kontrolu od strane nadležnog tijela koje izdaje Certifikat o provedenoj provjeri kakvoće temeljem kojeg se cjepivo kao imunološki lijek može staviti u promet. Cilj ovog rada je prikazati ne samo pravnu osnovu provjere kakvoće već i kako su uspoređeni rezultati dobiveni ispitivanjem u hrvatskome kontrolnom laboratoriju u odnosu na rezultate ispitivanja proizvođača. Rezultati pokazuju da postoje manja neslaganja rezultata ispitivanja različitih laboratorija koja su u ovisnosti s korištenim metodama/analitičkim postupcima (sličan ili identičan analitički postupak). Rezultati također pokazuju važnost ispitivanja koja se provode na gotovom proizvodu, neovisno o ispitivanjima provedenim na međuproizvodima, kao i važnost retestiranja koje provodi nadležno tijelo u svrhu osiguranja da se na tržištu nalaze samo imunološki lijekovi koji udovoljavaju zahtjevima kakvoće.

KLJUČNE RIJEČI: epidemiološka slika, nadležno tijelo, OCABR, OMCL, virus influence

\section{CORRESPONDING AUTHOR:}

Tamara Mandušić Nazor

Agency for Medicinal Products and Medical Devices

Ksaverska cesta 4, HR-10001 Zagreb

E-mail:tamara.mandusic@almp.hr 